\title{
RESPON KONSENTRASI NUTRISI HIDROPONIK TERHADAP TIGA JENIS TANAMAN SAWI (Brassica juncea L.)
}

\author{
Response of Hydroponic Nutrition Concentration to Three Types of Mustard Plant \\ (Brassica juncea L.) \\ Bagus Tripama dan Muhammad Rizal Yahya \\ Prodi Agroteknologi, Fakultas Pertanian, Universitas Muhammadiyah Jember \\ e-mail: 'bagustripama@unmuhjember.ac.id, 2prettyboy.rbg13@gmail.com
}

\begin{abstract}
ABSTRAK
Penelitian ini bertujuan untuk mengetahui pengaruh konsentrasi nutrisi yang tepat terhadap pertumbuhan dan produksi tanaman sawi. Penelitian ini dilaksanakan di Desa Gebang, Kecamatan Patrang, Kabupaten Jember. Waktu penelitian 5 bulan dari Januari sampai Mei 2018 dengan ketinggian tempat +89 meter di atas permukaan laut. Rancangan yang digunakan Split Plot (Petak Berbagi) terdapat dua faktor. Faktor petak utama adalah Konsentrasi Nutrisi AB mix terdiri dari 3 taraf: K1 : 1050 ppm, K2 : 1150 ppm, K3 : 1250 ppm. Faktor kedua sebagai anak petak adalah jenis Jenis Sawi (Brassica juncea L) ( V ) terdiri dari 3 jenis: J1 : Sawi Pagoda (Brassica narinosa), J2 : Sawi Hijau (Brassica rapa subsp. Chinensis), J3 : Sawi Pakcoy (Brassica rapa L). Hasil penelitian ini adalah perlakuan konsentrasi nutrisi berpengaruh nyata terhadap parameter tinggi tanaman pada semua umur tanaman, serta berpengaruh sangat nyata terhadap parameter jumlah daun umur 21 dan 28 hari setelah tanam (hst), berpengaruh nyata pada parameter jumlah dauh 35 hst. Perlakuan jenis sawi berpengaruh sangat nyata terhadap parameter tinggi tanaman semua umur, jumlah daun 14 sampai 42 hst dan bobot tanaman. Adapun interaksi antara konsentrasi nutrisi dan jenis sawi berpengaruh tidak nyata terhadap parameter tinggi tanaman pada semua umur, jumlah daun 14 dan 42 hst, panjang akar dan bobot tanaman, sedangkan parameter lainnya berpengaruh nyata pada parameter daun umur 21 hst dan berpengaruh sangat nyata pada parameter jumlah daun umur 28 dan 35 hst.
\end{abstract}

Kata Kunci : Hidroponik, Konsentrasi nutrisi, Jenis sawi

\section{ABSTRACT}

This study aims to determine the effect of concentrations of appropriate nutrients on the growth and production of mustard plants. This research was conducted in Gebang Village, Patrang District, Jember Regency. Research time is 5 months from January to May 2018 with altitude +89 meters above sea level.The design used by Split Plot which is applied to Complete Random Design (CRD) has two factors. The main factor is the AB mix Nutrition Concentration consisting of 3 levels: K1: 1050 ppm, K2: 1150 ppm, K3: 1250 ppm.The second factor is the type of Sawi (Brassica Juncea L) (V) consists of 3 types: J1: Mustard Pagoda (Brassica narinosa), J2: Green Mustard (Brassica rapa subsp. Chinensis), J3: Sawi Pakcoy (Brassica rapa L).The results of this study are the treatment of nutrient concentration has a significant effect on the parameters of plant height at all plant ages, and has a very significant effect on the parameters of the number of leaves aged 21 and 28 days after planting (hst), significantly affecting the number of parameters 35 days.The type of treatment has a very significant effect on the parameters of plant height of all ages, number of leaves 14 to 42 days and plant weights. The interaction between nutrient concentration and type had no significant effect on plant parameters at all ages, number of leaves 14 and 42 days, root length and plant weights, 
while other parameters significantly affected leaf parameters aged 21 hst and had a very significant effect on the number of leaf parameters. age 28 and $35 \mathrm{hst}$.

Keywords: Hydroponics, Nutrition concentration, Types of Mustard

\section{PENDAHULUAN}

Sawi (Brassica juncea) merupakan salah satu komoditas tanaman hortikultura dari jenis sayur-sayuran yang memiliki kandungan zat-zat gizi yang cukup tinggi. Sawi merupakan salah satu jenis sayuran daun yang umum dikonsumsi oleh masyarakat Indonesia. Tanaman sawi kaya akan sumber vitamin A, sehingga berguna dalam upaya mengatasi masalah kekurangan vitamin A atau penyakit rabun ayam sampai saat ini menjadi masalah di kalangan anak balita (Margiyanto, 2007). Dengan demikian sawi dapat membantu dalam peningkatan pola pangan beragam, bergizi, seimbang, dan aman yang dicanangkan oleh Kementerian Pertanian sehingga kualitas sumberdaya manusia juga akan meningkat. Pemanfaatan lahan sempit dan ruang kosong di perkotaan merupakan permasalahan umum di berbagai tempat, dan salah satu cara mengatasinya adalah dengan budidaya sayur secara hidroponik.

Menurut Parks dan Murray (2011), dalam sistem budidaya secara hidroponik perlu diberikan larutan nutrisi yang cukup, air, dan oksigen pada perakaran tanaman agar pertumbuhan tanaman baik. Nugraha (2015), menyatakan bahwa di antara faktor-faktor yang mempengaruhi sistem produksi tanaman secara hidroponik, larutan nutrisi menjadi salah satu faktor penentu yang paling penting dalam menentukan hasil dan kualitas tanaman khususnya pada tanaman sawi. Penelitian ini dilakukan bertujuan untuk mengetahui pengaruh pertumbuhan dan hasil pada tanaman sawi dengan menggunakan sistem budidaya hidroponik.

\section{METODE PENELITIAN}

Penelitian ini bertempat di Desa Gebang, Kecamatan Patrang, Kabupaten Jember. Tingkat ketinggian $+89 \mathrm{dpl}$. Alat yang digunakan pada penelitian ini adalah: Penggaris, Gunting, Gergaji besi/cutter, Alat tulis, Timbangan, Alat ukur ppm (TDS dan EC), pH meter, Label, Bak penyimpanan air, Sterofoam, rak besi (tempat bantalan dari bak penampung air nutrisi), timba. Bahan-bahan yang digunakan untuk penelitian ini adalah: Nutrisi AB MIX, Air, Benih sawi (sawi pagoda, sawi hijau, sawi pakcoy), Rockwool, Net pot, Kain flenel.

Rancangan percobaan yang digunakan dalam penelitian ini adalah Rancangan Split plot (Petak terbagi) yang diaplikasikan pada Rancangan Acak Lengkap (RAL), yang terdiri dari 2 faktor ( $3 \mathrm{X}$ 3), masing-masing diulang 3 kali.Faktor I (sebagai petak utama) adalah konsentrasi Nutrisi ( K ) terdiri dari 3 taraf: K1 : 1050 ppm, K2 : 1150 ppm, K3 : 1250 ppm.Faktor II (sebagai anak petak) adalah Jenis Sawi ( J ) terdiri dari 3 jenis: J1 : Sawi Pagoda, J2 : Sawi Hijau, J3 : Sawi Pakcoy.

\section{HASIL DAN PEMBAHASAN}

Hasil pengamatan dianalisis dengan menggunakan analisis ragam dengan rancangan acak kelompok model split plot dan jika terdapat pengaruh yang nyata atau 
sangat nyata maka akan dilanjutkan dengan uji jarak berganda Duncan. Adapun hasil analisis ragam terhadap masing-masing variabel pengamatan disajikan pada Tabel 1.

Tabel 1. Rangkuman hasil analisis ragam terhadap semua variabel pengamatan

\begin{tabular}{|c|c|c|c|c|c|c|}
\hline \multirow{3}{*}{$\begin{array}{r}\text { Parameter } \\
\text { Tinggi Tanaman } 7 \text { hst }\end{array}$} & \multicolumn{6}{|c|}{ F-hitung } \\
\hline & \multicolumn{2}{|c|}{$\begin{array}{l}\text { Konsentrasi } \\
\text { Nutrisi (K) }\end{array}$} & \multicolumn{2}{|c|}{ Jenis $(\mathbf{J})$} & \multicolumn{2}{|c|}{ Interaksi $\mathbf{K}$. } \\
\hline & 6,893 & $*$ & 86,446 & $* *$ & 1,302 & ns \\
\hline Tinggi Tanaman 14 hst & 7,542 & $*$ & 97,162 & $* *$ & 0,980 & ns \\
\hline Tinggi Tanaman $21 \mathrm{hst}$ & 6,171 & $*$ & 107,834 & $* *$ & 0,810 & ns \\
\hline Tinggi Tanaman 28 hst & 6,512 & $*$ & 97,534 & $* *$ & 1,013 & ns \\
\hline Tinggi Tanaman 35 hst & 6,476 & $*$ & 97,071 & $* *$ & 0,817 & ns \\
\hline Tinggi Tanaman 42 hst & 5,796 & $*$ & 99,689 & $* *$ & 0,760 & ns \\
\hline Jumlah Daun 7 hst & 2,211 & ns & 7,043 & ** & 1,809 & ns \\
\hline Jumlah Daun 14 hst & 4,402 & ns & 6,404 & $*$ & 1,553 & ns \\
\hline Jumlah Daun 21 hst & 13,797 & $* *$ & 21,802 & $* *$ & 5,272 & $*$ \\
\hline Jumlah Daun 28 hst & 16,415 & $* *$ & 19,605 & $* *$ & 6,690 & $* *$ \\
\hline Jumlah Daun 35 hst & 7,125 & $*$ & 24,990 & $* *$ & 5,862 & $* *$ \\
\hline Jumlah Daun 42 hst & 5,063 & ns & 26,645 & $* *$ & 3,057 & ns \\
\hline Panjang Akar & 2,101 & ns & 3,986 & $*$ & 0,529 & ns \\
\hline Bobot Tanaman & 8,332 & $*$ & 116,121 & $* *$ & 2,896 & ns \\
\hline
\end{tabular}

Keterangan: $\quad$ ns : berbeda tidak nyata.* : berbeda nyata.** : berbeda sangat nyata.

Berdasarkan Tabel 1, hasil analisis ragam menunjukkan bahwa perlakuan konsentrasi nutrisi berpengaruh sangat nyata terhadap parameter jumlah daun umur 21 dan 28hari setelah tanam (hst), serta berpengaruh nyata terhadap parameter tinggi tanaman pada semua umur tanaman, jumlah daun minggu umur 35 hst dan bobot tanaman. Adapun parameter jumlah daun umur 7, 14 dan 42 hst serta panjang akar berpengaruh tidak nyata. Perlakuan jenis berpengaruh nyata terhadap parameter jumlah daun umur 14 hst dan panjang akar, sedangkan parameter lainnya berpengaruh sangat nyata. Adapun interaksi antara konsentrasi nutrisi dan jenis berpengaruh nyata pada parameter jumlah daun umur 21 hst dan berpengaruh sangat nyata terhadap jumlah daun umur 28 hst dan 35 hst.

\section{Tinggi Tanaman}

Hasil analisis ragam menunjukkan konsentrasi nutrisi berpengaruh nyata terhadap tinggi tanaman pada semua umur pengamatan dilihat pada Tabel2.

Tabel 2. Tinggi tanaman semua umur yang dipengaruhi perlakuan konsentrasi nutrisi

\begin{tabular}{ccccccc}
\hline \multirow{2}{*}{ Jenis } & \multicolumn{6}{c}{ Rata-rata Tinggi Tanaman (cm) } \\
\cline { 2 - 7 } & $7 \mathrm{hst}$ & $14 \mathrm{hst}$ & $21 \mathrm{hst}$ & $28 \mathrm{hst}$ & $35 \mathrm{hst}$ & $42 \mathrm{hst}$ \\
\hline $1050 \mathrm{ppm}(\mathrm{K} 1)$ & $8,111 \mathrm{ab}$ & $9,778 \mathrm{ab}$ & $11,741 \mathrm{ab}$ & $14,296 \mathrm{ab}$ & $17,185 \mathrm{ab}$ & $20,667 \mathrm{ab}$ \\
$1150 \mathrm{ppm}(\mathrm{K} 2)$ & $7,593 \mathrm{~b}$ & $9,259 \mathrm{~b}$ & $11,111 \mathrm{~b}$ & $13,370 \mathrm{~b}$ & $16,259 \mathrm{~b}$ & $19,704 \mathrm{~b}$ \\
$1250 \mathrm{ppm}(\mathrm{K} 3)$ & $8,778 \mathrm{a}$ & $10,593 \mathrm{a}$ & $12,815 \mathrm{a}$ & $15,556 \mathrm{a}$ & $18,741 \mathrm{a}$ & $22,630 \mathrm{a}$ \\
\hline
\end{tabular}

Keterangan: Rata-rata yang diikuti huruf yang sama pada kolom yang sama menunjukkan berbeda tidak nyata pada Uji Duncan taraf $5 \%$. 
Tabel 2, menunjukkan bahwa hasil uji jarak berganda Duncan tinggi tanaman yang dipengaruhi perlakuan konsentrasi nutrisi, bahwa pada semua umur tanaman, perlakuan konsentrasi nutrisi $1250 \mathrm{ppm} \mathrm{K} 3$ ) berbeda tidak nyata dengan perlakuan konsentrasi nutrisi $1050 \mathrm{ppm}$ (K1), tetapi berbeda nyata dengan perlakuan $1150 \mathrm{ppm}$ (K2).

Perlakuan konsentrasi 1250 ppm (K3) cenderung memberikan tinggi tanaman yang tertinggi pada semua umur tanaman. Menurut hasil penelitian Mas'ud (2009) pemberian nutrisi dengan berbagai konsentrasi dapat dijadikan metode untuk menemukan konsentrasi yang tepat terhadap pertumbuhan tanaman sesuai dengan macam jenisnya. Semua hara yang terkandung pada nutrisi hidroponik adalah unsur esensial yang diperlukan tanaman dalam pertumbuhan dan perkembangannya. Apabila unsur hara makro dan mikro tidak lengkap ketersediaannya, dapat menghambat pertumbuhan dan perkembangan tanaman.

Interaksi antara konsentrasi nutrisi dan jenis juga berpengaruh tidak nyata pada semua umur tanaman. Tinggi tanaman yang dipengaruhi perlakuan jenis disajikan pada Tabel 3.

Tabel 3. Tinggi tanaman semua umur yang dipengaruhi perlakuan jenis.

\begin{tabular}{ccccccc}
\hline \multirow{2}{*}{ Jenis } & \multicolumn{6}{c}{ Rata-rata Tinggi Tanaman (cm) } \\
\cline { 2 - 7 } & 7 hst & 14 hst & 21 hst & $28 \mathrm{hst}$ & $35 \mathrm{hst}$ & $42 \mathrm{hst}$ \\
\hline Sawi Pagoda (J1) & $5,593 \mathrm{c}$ & $6,593 \mathrm{c}$ & $7,852 \mathrm{c}$ & $9,630 \mathrm{c}$ & $11,667 \mathrm{c}$ & $14,074 \mathrm{c}$ \\
Sawi Hijau (J2) & $10,185 \mathrm{a}$ & $12,333 \mathrm{a}$ & $14,963 \mathrm{a}$ & $18,074 \mathrm{a}$ & $21,815 \mathrm{a}$ & $26,333 \mathrm{a}$ \\
Sawi Pakcoy (J3) & $8,704 \mathrm{~b}$ & $10,704 \mathrm{~b}$ & $12,852 \mathrm{~b}$ & $15,519 \mathrm{~b}$ & $18,704 \mathrm{~b}$ & $22,593 \mathrm{~b}$ \\
\hline
\end{tabular}

Keterangan: Rata-rata yang diikuti huruf yang sama pada kolom yang sama menunjukkan berbeda tidak nyata pada Uji Duncan taraf $5 \%$.

Berdasarkan Tabel 3, hasil uji jarak berganda Duncan terhadap tinggi tanaman 7 , $14,21,28,35$ dan 42 hst menunjukkan bahwa masing-masing perlakuan jenis saling berbeda antara satu dengan lainnya. Sawi Hijau (J2) menghasilkan rata-rata yang tertinggi pada masing-masing umur tanaman dan kemudian diikuti oleh Sawi Pakcoy (J3) dan Sawi Pagoda (J1). Rata-rata tinggi tanaman tertinggi adalah pada jenis Sawi Hijau (J2) yaitu sebesar 26,33 cm pada umur tanaman $42 \mathrm{hst}$.

Tanaman sawi hijau berakar serabut yang tumbuh dan menyebar ke semua arah disekitar permukaan tanah, tidak membentuk krops. Tanaman sawi hijau memiliki batang sejati pendek dan tegap terletak pada bagian dasar yang berada di dalam tanah. Daun tanaman sawi hijau berbentuk bulat, tidak berbulu, berwarna hijau muda sampai hijau tua. Pelepah-pelepah daun tersusun saling membungkus dengan pelepah daun yang lebih muda tetapi membuka (Cahyono, 2003). Hal inilah yang diduga menjadikan sawi hijau memberikan respon yang lebih terhadap tinggi tanaman. Tanaman sawi hijau (Brassica junceaL.)tumbuh baik pada tanah yang subur, gembur, mudah mengikat air dan kaya bahan organik. Keasaman tanah yang baik untuk pertumbuhan ini adalah $\mathrm{pH}$ 6-7. Salah satu cara untuk memperoleh pertumbuhan tanaman yang baik adalah dengan cara pemupukan. Pemupukan merupakan suatu usaha penambahan unsur-unsur hara dalam tanah yang dapat meningkatkan produksi kesuburan tanah dan mutu hasil tanaman. Pemberian pupuk yang kurang tepat baik jenis, dosis, waktu dan cara pemupukan yang digunakan akan menyebabkan tanaman terganggu, sehingga tanaman tersebut tidak dapat 
menghasilkan seperti apa yang diharapkan. Unsur N, P, dan K merupakan unsur-unsur esensial dalam jumlah yang cukup banyak (Istarofah, 2017).

\section{Jumlah Daun}

Hasil analisis ragam menunjukkan perlakuan konsentrasi nutrisi berpengaruh nyata terhadap jumlah daun pada umur tanaman 42 hst dan berpengaruh sangat nyata pada umur tanaman 21 dan 28 hst. Perlakuan jenis berpengaruh sangat nyata terhadap jumlah daun pada umur tanaman 7, 21, 28, 35 dan 42 hst serta berpengaruh nyata pada umur tanaman 14 hst. Adapun interaksi antara konsentrasi nutrisi dan jenis juga berpengaruh sangat nyata pada umur tanaman 28 dan 35 hst serta berpengaruh nyata pada umur tanaman 21 hst.

Jumlah daun dipengaruhi konsentrasi nutrisi pada umur 7, 14 dan 35 hst berpengaruh tidak nyata pada Konsentrasi Nutrisi (K) dapat dilihat pada Gambar 1.

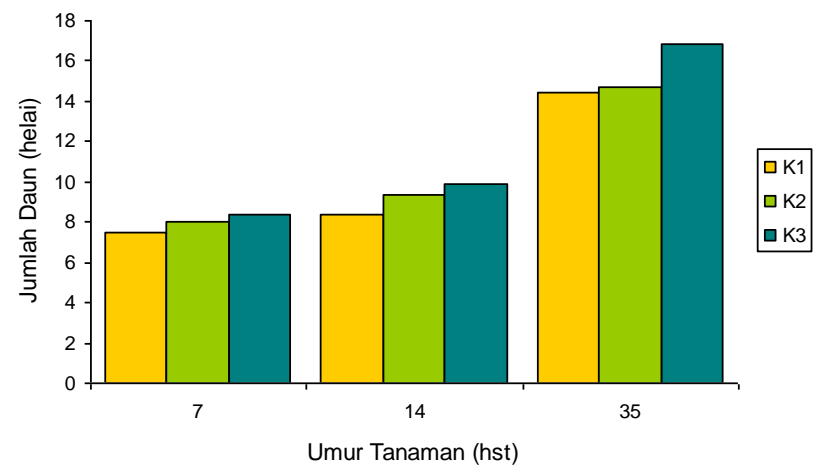

Gambar 1. Respon tinggi tanaman terhadap berbagai konsentrasi nutrisi pada umur 7, 14 dan 35 hst.

Berdasarkan Gambar 1, jumlah daun dari umur 7, 14 dan 35 hst yang dipengaruhi konsentrasi nutrisi menunjukkan perbedaan tidak nyata pada semua jenis, meliputi Sawi Pagoda (J1), Sawi Hijau (J2) dan Sawi Pakcoy (J3).

Menurut Buntoro (2014), faktor eksternal merupakan faktor yang disebabkan dari luar tanaman dapat berupa faktor lingkungan. Faktor internal atau faktor yang berasal dari dalam tanaman dapat berupa faktor fisiologis dan genetika tanaman. Semua hara yang terkandung pada nutrisi hidroponik adalah unsur esensial yang diperlukan tanaman dalam pertumbuhan dan perkembangannya.

Rata-rata jumlah daun tanaman sawi yang dipengaruhi perlakuan konsentrasi nutrisi pada umur tanaman 21, 28 dan 42 hst disajikan pada Tabel 4. 
Tabel 4. Jumlah daun umur 21, 28 dan 42 hst yang dipengaruhi perlakuan konsentrasi nutrisi.

\begin{tabular}{cccc}
\hline \multirow{2}{*}{ Konsentrasi Nutrisi } & \multicolumn{3}{c}{ Rata-rata Jumlah Daun } \\
\cline { 2 - 4 } $1050 \mathrm{ppm}(\mathrm{K} 1)$ & $21 \mathrm{hst}$ & $28 \mathrm{hst}$ & $42 \mathrm{hst}$ \\
\cline { 2 - 4 } $1150 \mathrm{ppm}(\mathrm{K} 2)$ & $10,444 \mathrm{~b}$ & $12,407 \mathrm{~b}$ & $19,259 \mathrm{~b}$ \\
$1250 \mathrm{ppm}(\mathrm{K} 3)$ & $11,704 \mathrm{~b}$ & $13,296 \mathrm{~b}$ & $20,852 \mathrm{ab}$ \\
& $13,667 \mathrm{a}$ & $15,630 \mathrm{a}$ & $21,407 \mathrm{a}$ \\
\hline
\end{tabular}

Keterangan: Rata-rata yang diikuti huruf yang sama pada kolom yang sama menunjukkan berbeda tidak nyata pada Uji Duncan taraf $5 \%$.

Tabel 4 menunjukkan bahwa hasil uji jarak berganda Duncan jumlah daun yang dipengaruhi perlakuan konsentrasi nutrisi, bahwa pada umur tanaman 21 dan 28 hst, perlakuan konsentrasi nutrisi (K3) berbeda nyata dengan perlakuan konsentrasi nutrisi (K2) dan (K1). Sedangkan antara perlakuan konsentrasi nutrisi (K2) dan (K1) berbeda tidak nyata. Perlakuan konsentrasi nutrisi (K3) menghasilkan rata-rata jumlah daun yang tertinggi pada umur tanaman 21 dan 28 hst, yaitu 14 helai (21 hst) dan 16 helai ( 28 hst). Pada umur tanaman 42 hst, perlakuan konsentrasi nutrisi (K3) berbeda tidak nyata dengan perlakuan konsentrasi nutrisi (K2) tetapi berbeda nyata pada konsentrasi nutrisi (K1). Sedangkan antara perlakuan konsentrasi nutrisi (K2) dan (K1) berbeda tidak nyata.

Perlakuan konsentrasi nutrisi (K3) cenderung menghasilkan jumlah daun tertinggi yaitu sebesar 21 helai. Hal itu disebabkan dalam proses pembentukan organ vegetatif daun, tanaman membutuhkan unsur hara nitrogen dalam jumlah banyak. Tanaman yang hanya dipanen daunnya seperti kubis, selada, sawi, kangkung dan bayam membutuhkan unsur nitrogen tinggi. Tanaman-tanaman tersebut lebih difokuskan pada pembentukan daunnya, sehingga fase vegetatif dari tanaman tersebut dirangsang untuk lebih dominan. Pupuk organik yang digunakan mempunyai nilai nitrogen tinggi sehingga sangat sesuai untuk memacu proses pembentukan daun tanaman sawi. Karena nitrogen merupakan unsur hara pembentuk asam amino dan protein sebagai bahan dasar tanaman dalam menyusun daun (Haryanto, 2003). Apabila kebutuhan unsur $\mathrm{N}$ tercukupi, maka dapat meningkatkan pertumbuhan tanaman. Seperti diketahui unsur N pada tanaman berfungsi untuk meningkatkan pertumbuhan daun sehingga daun akan menjadi banyak jumlahnya dan akan menjadi lebar dengan warna yang lebih hijau yang akan meningkatkan kadar protein dalam tubuh tanaman. Batang tanaman pagoda pendek sekali dan beruas-ruas sehingga hampir tidak kelihatan. Struktur bunga pagoda tersusun dalam tangkai bunga (inflorescentia) yang tumbuh memanjang (tinggi) dan bercabang banyak. Tiap kuntum bunga pagoda terdiri atas empat helai daun kelopak, empat helai daun mahkota bunga berwarna kuning cerah, empat helai benang sari dan satu buah putik yang berongga dua (Cahyono, 2003). Sistem perakaran tanaman pagoda memiliki akar tunggang dan cabang-cabang akar yang bentuknya bulat panjang (silindris) menyebar ke semua arah dengan kedalaman antara $(30-50) \mathrm{cm}$.

Rata-rata jumlah daun tanaman sawi yang dipengaruhi konsentrasi nutrisi dan jenis pada kombinasi perlakuan umur tanaman 3, 4 dan 42 hst disajikan pada Tabel 6. 
Tabel 5 Jumlah daun umur 21, 28 dan 35 hst yang dipengaruhi kombinasi perlakuan konsentrasi nutrisi dan jenis

\section{Kombinasi Perlakuan}

K1J1 (kons. 1050 ppm, var. pagoda) K1J2 (kons. 1050 ppm, var. hijau) K1J3 (kons. 1050 ppm, var. pakcoy) K2J1 (kons. 1150 ppm, var. pagoda) K2J2 (kons. 1150 ppm, var. hijau) K2J3 (kons. 1150 ppm, var. pakcoy) K3J1 (kons. 1250 ppm, var. pagoda) K3J2 (kons. 1250 ppm, var. hijau) K3J3 (kons. 1250 ppm, var. pakcoy)

\begin{tabular}{ccc}
\multicolumn{3}{c}{ Rata-rata Jumlah Daun (helai) } \\
\hline $21 \mathrm{hst}$ & $28 \mathrm{hst}$ & $35 \mathrm{hst}$ \\
\hline $10,000 \mathrm{e}$ & $12,000 \mathrm{~cd}$ & $15,000 \mathrm{bcd}$ \\
$9,000 \mathrm{e}$ & $10,889 \mathrm{~d}$ & $12,333 \mathrm{~cd}$ \\
$12,333 \mathrm{bc}$ & $14,333 \mathrm{bc}$ & $15,889 \mathrm{bc}$ \\
$12,111 \mathrm{bcd}$ & $13,778 \mathrm{bcd}$ & $15,667 \mathrm{bc}$ \\
$10,111 \mathrm{de}$ & $11,000 \mathrm{~d}$ & $11,667 \mathrm{~d}$ \\
$12,889 \mathrm{bc}$ & $15,111 \mathrm{~b}$ & $16,667 \mathrm{~b}$ \\
$16,333 \mathrm{a}$ & $20,222 \mathrm{a}$ & $22,667 \mathrm{a}$ \\
$11,000 \mathrm{cde}$ & $11,556 \mathrm{~cd}$ & $11,667 \mathrm{~d}$ \\
$13,667 \mathrm{~b}$ & $15,111 \mathrm{~b}$ & $16,111 \mathrm{~b}$ \\
\hline
\end{tabular}

Keterangan: Rata-rata yang diikuti huruf yang sama pada kolom yang sama menunjukkan berbeda tidak nyata pada Uji Duncan taraf $5 \%$.

Tabel 5 menunjukkan bahwa hasil uji jarak berganda Duncan jumlah daun yang dipengaruhi kombinasi perlakuan konsentrasi nutrisi dan jenis pada umur tanaman 21 hst, bahwa kombinasi perlakuan K3J1 (konsentrasi nutrisi 1250 ppm pada jenis pagoda) berbeda nyata dengan kombinasi perlakuan lainnya. Kombinasi perlakuan K3J3 (konsentrasi nutrisi $1250 \mathrm{ppm}$ pada jenis pakcoy) berbeda tidak nyata dengan kombinasi perlakuan K2J3 (konsentrasi nutrisi 1150 ppm pada jenis pakcoy), K1J3 (konsentrasi nutrisi 1050 ppm pada jenis pakcoy) dan K2J1 (konsentrasi nutrisi 1150 ppm pada jenis pagoda), tetapi berbeda nyata dengan kombinasi perlakuan lainnya. Kombinasi perlakuan K2J3 (konsentrasi nutrisi 1150 ppm pada jenis pakcoy) dan K1J3 (konsentrasi nutrisi $1050 \mathrm{ppm}$ pada jenis pakcoy) berbeda tidak nyata dengan kombinasi perlakuan K2J1 (konsentrasi nutrisi 1150 ppm pada jenis pagoda) dan K3J2 (konsentrasi nutrisi 1250 ppm pada jenis hijau), tetapi berbeda nyata kombinasi perlakuan lainnya. Kombinasi perlakuan K3J1 (konsentrasi nutrisi $1250 \mathrm{ppm}$ pada jenis pagoda) menghasilkan jumlah daun tertinggi yaitu 16 helai.

Pada umur tanaman 28 hst, bahwa kombinasi perlakuan K3J1 (konsentrasi nutrisi 1250 ppm pada jenis pagoda) berbeda nyata dengan kombinasi perlakuan lainnya. Kombinasi perlakuan K2J3 (konsentrasi nutrisi 1150 ppm pada jenis pakcoy) dan kombinasi perlakuan K3J3 (konsentrasi nutrisi 1250 ppm pada jenis pakcoy) berbeda tidak nyata dengan kombinasi perlakuan K1J3 (konsentrasi nutrisi 1050 ppm pada jenis pakcoy) dan K2J1 (konsentrasi nutrisi 1150 ppm pada jenis pagoda), tetapi berbeda nyata dengan kombinasi perlakuan lainnya. Kombinasi perlakuan K3J1 (konsentrasi nutrisi 1250 ppm pada jenis pagoda) menghasilkan jumlah daun tertinggi yaitu 20 helai.

Pada umur tanaman 35 hst, bahwa kombinasi perlakuan K3J1 (konsentrasi nutrisi 1250 ppm pada jenis pagoda) berbeda nyata dengan kombinasi perlakuan lainnya. Kombinasi perlakuan K2J3 (konsentrasi nutrisi 1150 ppm pada jenis pakcoy) dan kombinasi perlakuan K3J3 (konsentrasi nutrisi 1250 ppm pada jenis pakcoy) berbeda tidak nyata dengan kombinasi perlakuan K1J3 (konsentrasi nutrisi $1050 \mathrm{ppm}$ pada jenis pakcoy), K2J1 (konsentrasi nutrisi 1150 ppm pada jenis pagoda) dan K1J1 (konsentrasi nutrisi 1050 ppm pada jenis pagoda), tetapi berbeda nyata dengan kombinasi perlakuan 
lainnya. Kombinasi perlakuan K3J1 (konsentrasi nutrisi 1250 ppm pada jenis pagoda) menghasilkan jumlah daun tertinggi yaitu 23 helai.

Pada budidaya tanaman secara hidroponik garam-garam mineral dilarutkan dalam air dengan komposisi tertentu. Campuran garam-garam mineral dan air ini biasa disebut larutan nutrisi. Menurut Lestari (2009), nutrisi yang diberikan pada tanaman harus dalam komposisi yang tepat. Bila kekurangan atau kelebihan, akan mengakibatkan pertumbuhan tanaman terganggu dan hasil produksi yang diperolehpun kurang maksimal. Pupuk hidroponik (larutan nutrisi hidroponik) mengandung semua nutrisi mikro dan makro dalam jumlah sesuai, berbeda dengan pupuk reguler (pupuk tanah). Selain itu, pupuk hidroponik juga bersifat lebih stabil dan cepat larut dalam air karena berada dalam bentuk lebih murni.

\section{Panjang Akar}

Rata-rata panjang akar berkisar antara 15,22 cm sampai dengan 33,33 cm. Hasil analisis ragam menunjukkan perlakuan konsentrasi nutrisi berpengaruh tidak nyata terhadap panjang akar. Perlakuan jenis berpengaruh nyata terhadap panjang akar. Adapun interaksi antara konsentrasi nutrisi dan jenis juga berpengaruh tidak nyata terhadap panjang akar.

Rata-rata panjang akar yang dipengaruhi konsentrasi nutrisi diperoleh pada saat panen atau tanaman berumur 42 hstberpengaruh tidak nyata pada Konsentrasi Nutrisi (K) dapat dilihat pada Gambar 2.

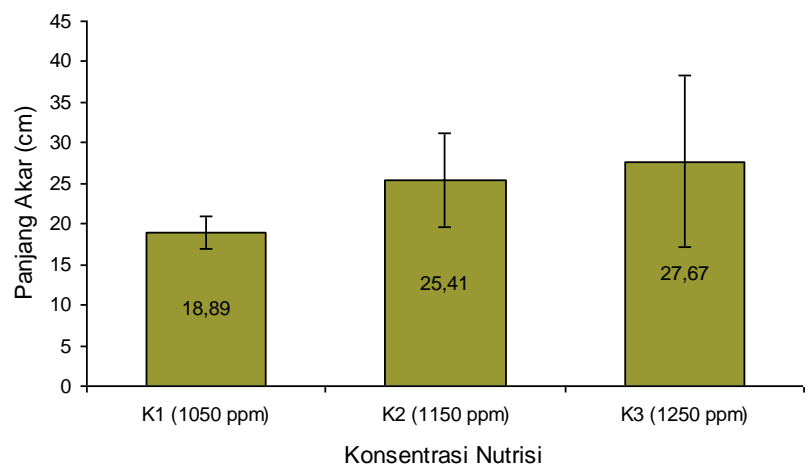

Gambar 2. Respon panjang akar terhadap berbagai konsentrasi nutrisi pada umur 42 hst.

Berdasarkan Gambar 2, panjang pada akar umur 42 hst yang dipengaruhi konsentrasi nutrisi menunjukkan perbedaan tidak nyata pada semua jenis, meliputi Sawi Pagoda (J1), Sawi Hijau (J2) dan Sawi Pakcoy (J3).

Menurut Lakitan (2007), pemberian zat pengatur tumbuh dalam konsentrasi yang sesuai dapat meningkatkan morfogenesis tanaman, tetapi apabila zat pengatur tumbuh diberikan dalam konsentrasi yang berlebihan maka akan menjadi penghambat bagi pertumbuhan morfogenesis tanaman.

Rata-rata panjang akar tanaman sawi yang dipengaruhi perlakuan jenis disajikan pada Tabel 6 
Tabel 6. Panjang akar tanaman sawi yang dipengaruhi perlakuan jenis.

\begin{tabular}{llc}
\hline & Jenis & Rata-rata (cm) \\
\hline & Sawi Pagoda (J1) & $19,667 \mathrm{~b}$ \\
& Sawi Hijau (J2) & $27,111 \mathrm{a}$ \\
& Sawi Pakcoy (J3) & $25,185 \mathrm{ab}$ \\
\hline Keterangan : & Rata-rata yang diikuti huruf yang sama pada kolom yang sama menunjukkan \\
& berbeda tidak nyata pada Uji Duncan taraf 5\%.
\end{tabular}

Berdasarkan Tabel 6, hasil uji jarak berganda Duncan terhadap panjang akar tanaman sawi menunjukkan bahwa perlakuan jenis Sawi Hijau (J2) berbeda tidak nyata dengan perlakuan jenis Sawi Pakcoy (J3), tetapi berbeda nyata dengan jenis Sawi Pagoda (J1). Sedangkan antara perlakuan jenis Sawi Pakcoy (J3) dan Sawi Pagoda (J1) berbeda tidak nyata. Perlakuan jenis Sawi Hijau (J2) cenderung menghasilkan panjang akar tertinggi yaitu sebesar $27,11 \mathrm{~cm}$.

Berdasarkan hasil yang diperoleh bahwa perbedaan jenis menunjukkan respons yang berbeda terhadap panjang akar. Kemampuan pengambilan air secara maksimal dengan perluasan dan kedalaman sistem perakaran. pendekatan kedua dengan melihat kemampuan tumbuhan mempertahankan turgor melalui penurunan potensial osmotik. Tiap jenis tanaman memiliki kemampuan yang berbeda dalam merespons cekaman air termasuk perubahan morfologi akar baik untuk parameter bobot kering maupun panjang akar. Munns (2002) mengklasifikasikan berdasarkan tingkat waktu dimana respon awal terjadi penyusutan seketika laju pemanjangan daun dan akar yang kemudian diikuti dengan penyembuhan sebagian lalu laju pemanjangan akar kembali normal tetapi lebih rendah dari laju sebelumnya dan akhirnya pertumbuhan daun lebih dipengaruhi daripada pertumbuhan akar dimana laju pertumbuhan luas daun berkurang.

\section{Bobot Tanaman}

Rata-rata bobot tanaman berkisar antara 8,89 g sampai dengan 99,56 g. Hasil analisis ragam menunjukkan perlakuan konsentrasi nutrisi berpengaruh tidak nyata terhadap bobot tanaman. Perlakuan jenis berpengaruh sangat nyata terhadap bobot tanaman. Adapun interaksi antara konsentrasi nutrisi dan jenis juga berpengaruh tidak nyata terhadap bobot tanaman.

Rata-rata bobot tanaman yang dipengaruhi konsentrasi nutrisidiperoleh pada saat panen atau tanaman berumur 42 hstberpengaruh nyata pada berbagai konsentrasi nutrisi (K) dan disajikan pada Tabel 7

Tabel 7. Bobot tanaman sawi yang dipengaruhi perlakuan konsentrasi nutrisi

\begin{tabular}{cc}
\hline Konsentrasi Nutrisi & Rata-rata $(\mathbf{g})$ \\
\hline $1050(\mathrm{~K} 1)$ & $35,074 \mathrm{~b}$ \\
$1150(\mathrm{~K} 2)$ & $55,037 \mathrm{a}$ \\
$1250(\mathrm{~K} 3)$ & $55,296 \mathrm{a}$ \\
\hline
\end{tabular}

Keterangan: Rata-rata yang diikuti huruf yang sama pada kolom yang sama menunjukkan berbeda tidak nyata pada Uji Duncan taraf $5 \%$.

Tabel 7. menunjukkan bahwa hasil uji jarak berganda Duncan terhadap bobot tanaman yang dipengaruhi perlakuan konsentrasi nutrisi, bahwa perlakuan konsentrasi nutrisi 1250 ppm (K3) dan 1150 ppm (K2) berbeda nyata dengan perlakuan konsentrasi 
nutrisi $1050 \mathrm{pm}(\mathrm{K} 1)$. Konsentrasi nutrisi $1250 \mathrm{ppm}$ (K3) cenderung menghasilkan bobot tanaman tertinggi, yaitu 55,296 g. Menurut Darmawan dan Baharsjah (2010), pertumbuhan tanaman dapat didefenisikan sebagai bertambah besarnya tanaman yang diikuti oleh peningkatan bobot kering. Proses pertumbuhan tanaman terdiri dari pembelahan sel kemudian diikuti oleh pembesaran sel dan terakhir adalah diferensiasi sel. Rata-rata bobot tanaman yang dipengaruhi perlakuan jenis disajikan pada Tabel 8 .

Tabel 8. Bobot tanaman sawi yang dipengaruhi perlakuan jenis.

\begin{tabular}{lc}
\hline Jenis & Rata-rata (g) \\
\hline Sawi Pagoda (J1) & $16,815 \mathrm{c}$ \\
Sawi Hijau (J2) & $46,963 \mathrm{~b}$ \\
Sawi Pakcoy (J3) & $81,630 \mathrm{a}$ \\
\hline
\end{tabular}

Keterangan: Rata-rata yang diikuti huruf yang sama pada kolom yang sama menunjukkan berbeda tidak nyata pada Uji Duncan taraf $5 \%$.

Berdasarkan Tabel 8, hasil uji jarak berganda Duncan terhadap bobot tanaman sawi menunjukkan bahwa masing-masing perlakuan jenis Sawi berbeda nyata antara satu dengan lainnya. Perlakuan jenis Sawi Pakcoy (J3) menghasilkan bobot tanaman tertinggi yaitu sebesar 81,63 g. Jenis unggul dengan karakteristik sifat tanaman yang lebih baik dapat tetap berdaya hasil tinggi. Perbedaan susunan genetik merupakan salah satu faktor penyebab keragaman penampilan tanaman. Program genetik yang akan diekspresikan pada berbagai sifat tanaman yang mencakup morfologi tanaman yang menghasilkan keragaman pertumbuhan tanaman. Keragaman penampilan tanaman akibat perbedaan susunan genetik selalu mungkin terjadi sekalipun bahan tanaman yang digunakan berasal dari jenis tanaman yang sama. Secara genetis sebenarnya dua tanaman atau lebih tidak akan sama pertumbuhannya, sudah banyak laporan penelitian yang dipublikasikan bahwa terdapat keragaman baik dalam spesies maupun antar spesies tanaman. Keragaman yang ditemukan meliputi sifat morfologi atau yang tampak (fenotip) maupun yang tidak tampak (genetik) (Swasti, 2007).

\section{KESIMPULAN}

\section{Kesimpulan}

Berdasarkan hasil penelitian dan pembahasan tentang respon konsentrasi nutrisi hidroponik terhadap tiga jenis sawi (Brassica juncea L.), maka dapat disimpulkan bahwa:

1. Perlakuan konsentrasi nutrisi 1250 ppm memberikan respon yang terbaik terhadap pertumbuhan tanaman sawi .

2. Jenis Sawi Hijau (J2 memberikan respon yang terbaik pada tinggi tanaman dan ,jenis Sawi Pagoda (J1) perlakuan terbaik pada jumlah daun. Sedangkan bobot tanaman ,jenis Sawi Pakcoy (J3) sebagai perlakuan terbaik.

3. Konsentrasi nutrisi $1250 \mathrm{ppm}$ pada jenis pagoda (K3J1) sebagai perlakuan kombinasi terbaik. 


\section{DAFTAR PUSTAKA}

A. Toshiki, editor. Cina: InTech. Wasiaturrohmah. 2008. Respon Plasma Nutfah Kedelai (Glycine $\max ($ L.) Merill) terhadap Keracunan Fe. Universitas Negeri Malang, Malang. Skripsi.

Alviani,Puput. Bertanam hidroponik untuk pemula. Jakarta: Bibit Publisher, 2016.

Buntoro, B.H. dkk. 2014. Pengaruh Takaran Pupuk Kandang dan Intensitas Cahaya Terhadap Pertumbuhan dan Hasil Temu Putih (Curcuma zedoaria L.). Vegetalika Vol.3(4).

Bussell W. T., Mckennie S. 2004. Rockwool in horticulture, and its importance and sustainable use in New Zealand // New Zealand. Journal of Crop and Horticultural Science. 32 (1): 29-37.

Cahyono, B. 2003. Teknik dan Strategi Budi Daya Sawi Hijau. Yayasan Pustaka Nusantara, Yogyakarta.

Darmawan J dan J. S. Baharsjah, 2010. Dasar-dasar Fisiologi Tanaman. SITC. Jakarta.

Gardner, F.P., R. B. Pearce dan R.G. Mitchell. 1991. Fisiologi Tanaman Budidaya. Terjemahan Susilo, H. Jakarta: UI Press.

Givnish, J. T. 1988. Adaptation to Sun and Shade a Whole-Plant Perspective. Aust. J. Plant Physol. (15): 63-92.

Handayani, T., A. Fibriyanti, dan I. Pratiwi. 2007. Kajian Peningkatan Kandungan Zat Besi (Fe), Seng (Zn), dan Beta Karoten pada Tanaman Singkong (Manihot esculenta Crantz sin.) melalui Teknologi Biofortifikasi. Karya Tulis Ilmiah. Bogor: Institut Pertanian Bogor.

Harjoko. 2009. Studi Macam Media dan Debit Aliran Terhadap Pertumbuhan dan Hasil Tanaman Sawi (Brassica Juncea L.) Secara Hidroponik NFT. Agrosains 11. (2): $58-62$.

Haryanto, Eko. 2003. Sawi dan Selada. Jakarta : Penebar Swadaya.

Haryanto, T. Suhartini dan E. Rahayu. 2002. Tanaman Sawi dan Selada. Depok: Penebar Swadaya.

Istarofah, Zuchrotus Salamah. 2017. Pertumbuhan tanaman sawi hijau (Brassica juncea L.)dengan pemberian kompos berbahan dasar daun paitan (Thitonia diversifolia). Jurnal Bio-site. 3(1): 39-46.

Karsono, S. 2013. Exploring Classroom Hydroponics. Parung Farm. Bogor. 36 hlm.

Kemas, Ali H. 2009. Dasar-dasar Ilmu Tanah. Rajawali Pers, Jakarta. Harjadi. 1991. Pengantar Agronomi. PT Gramedia Pustaka Utama. Jakarta.

Lakitan, B. 2007. Dasar-dasar Fisiologi tumbuhan. PT. Raja Grafindo Persada. Jakarta.

Lee, C. W., I. S. So., S. W. Jeong., dan M. R. Huh. 2010. Application of Subirrigation Using Capillary Wick System to Pot Production. Journal of Agriculture \& Life Science 44. (3): 7-14.

Lingga, P. 2005. Hidroponik Bercocok Tanam Tanpa Tanah. Penebar Swadaya. Jakarta. Hal 80.

Lingga, P. 2011. Hidroponik Bercocok Tanam Tanpa Tanah. Cetakan XXXII. Penerbit Penebar Swadaya. Jakarta. 
Margiyanto, E. 2007. Hortikultura. Bantul : Cahaya Tani. Marhaba, D. B. 1998. Hydroponic Systems. Horticultural Engineering. 13 (4): 1-10.

Mashego, C. D. 2001. The Production of Vegetable Crops Under Protection For SmallScale Farming Situations. Departement of Plant Production and Soil Science. University of Pretoria.

Mas'ud, Hidayati. 2009. Sistem Hidroponik dengan Nutrisi dan Media Tanam Berbeda terhadap Pertumbuhan dan Hasil Selada. Program Studi Budidaya Pertanian. Fakultas Pertanian. Universitas Tadulako. Palu.

Maulana, Yoga Nugraha. 2010. Kajian Penggunaan Pupuk Organik dan Jenis Pupuk N terhadap kadar $N$ tanah, serapan $N$ dan Hasil Tanaman sawi 64 (Brassica juncea l.) Pada Tanah Litosol Gemolong. Skripsi : Jurusan Ilmu Tanah Fakultas Pertanian Universitas Negeri Sebelas Maret.

Moerhasrianto, P. 2011. Respon Pertumbuhan Tiga Macam Sayuran pada Berbagai Konsentrasi Nutrisi Hidroponik. Jember: Fakultas Pertanian, Universitas Jember.

Munns, R. 2002. Comparative Physiology of Salt and Water Stress. Journal of Plant cell and environment. 2(5): 29-250.

Nugraha, Rizqi Utami. 2015. Sumber Sebagai Hara Pengganti AB mix pada Budidaya Sayuran Daun Secara Hidroponik. J. Hort Indonesia 6 (1): 11- 19. April 2015.

Nugraha, R. U. 2014. Sumber Hara Sebagai Pengganti AB mix pada Budidaya Sayuran

Daun Secara Hidroponik. Departemen Agronomi dan Holtikultura: Institut

Pertanian Bogor.

Parks, S., C. Murray. 2011. Leafy Asean Vegetables and Their Nutrion in Hydroponics. State of New South Wales. Australian.

Polii, M. G. M. 2009. Respon Produksi Tanaman Kangkung terhadap Variasi Waktu Pemberian Pupuk Kotoran Ayam. Soil Environment. (7) 1: 18-22.

Priandoko, A. D., S. Parwanayoni., dan I. K. Sundra. 2000. Kandungan Logam Berat (Pb dan Cd) pada sawi hijau (Brassica rapa l. Subsp. Perviridis Bailey) dan Wortel (Paucus Carrota L. Var. Sativa Hoffim) yang beredar di Koda Denpasar. Jurnal Simbiosis. 1 (1): 9-20.

Rahayu, Estu. 2003. Bertanam Sayuran Sawi. Jakarta :Penebar Swadaya.

Rosliani, R., N. Sumarni., 2005. Budidaya Tanaman Sayuran Dengan Sistem Hidroponik. Bandung: Balai Penelitian Tanaman Sayuran.

Rubatzky, Vincent. E., dan M. Yamaguchi. 1998a. Sayuran Dunia 1, Prinsip, Produksi dan Gizi, Edisi Kedua. ITB Ganesha. Bandung.

Rukmana, R. 1994. Bertanam Petsai dan Sawi. Yogyakarta : Kanisius.

Saribun, S. D. 2008. Pengaruh Pupuk Majemuk Npk Pada Berbagai Dosis Terhadap PH, P-Potensial Dan P-Tersedia Serta Hasil Caysin (Brassica Juncea) Pada Fluventic Eutrudepts Jatinangor. Skripsi Jurusan Ilmu Tanah Fakultas Pertanian. UNPAD.

Siswadi. 2008. Berbagai Formulasi Kebutuhan Nutrisi Pada Sistem Hidroponik. Jurnal Inovasi Pertanian. 7 (1): 103-110.

Suhardjono, H., dan Y. Koentjoro. 2008. Kajian Hasil Pembuatan Nutrisi Hidroponik Secara Bioteknik Dari Bahan Sampah Organik. Jurnal Pertanian Mapeta. 11 (1): 57-64. 
Suleman, D. Cindra, Nelson, Pomalingo, Nurmi. 2013. Pertumbuhan Dan Produksi Tanaman Sawi (Brassica Juncea L.) dengan Pemberian Dosis Pupuk Organik Kotoran Ayam. 1-10.

Suryawati, S., A. Djunaedy., dan A. Triendari.2007. Respon Tanaman Sambiloto (Andrographis Paniculatha, Ness) Akibat Naungan dan Selang Penyiraman Air. Embryo. 4 (2): 146-156.

Susila, D. A., dan Y. Koerniawati.2004. Pengaruh Volume dan Jenis Media Tanam pada Pertumbuhan dan Hasil Tanaman Selada (Lactuca sativa) dalam Teknologi Hidroponik Sistem Terapung. Bul. Agron.. 32 (3): 16-21.

Sutiyoso, Y. 2003. Meramu Pupuk Hidroponik. Penebar Swadaya. Jakarta. Hal 122.

Swasti, E. 2007.Fisiologi dan Pewarisan Sifat Efisiensi Fosfor pada Padi Gogo dalam Keadaan Tercekam Al. Tesis Program Pasca Sarjana. Bogor: Institut Pertanian Bogor.

Tellez, T. dan F.C.G. Merino. 2012. Nutrient Solutions For Hydroponic Systems.

Untung, O. 2000. Hidroponik Sayuran Sistem NFT (Nutrient Film Technique). Penerbit Penebar Swadaya. Jakarta.

Widiastoety, D., dan F. A. Bahar. 1995. Pengaruh Intensitas Cahaya Terhadap Pertumbuhan Anggrek Dendrobium. J. Hort. 5 (4): 72-75.

Wijaya, Kelik. 2010. Pengaruh Konsentrasi dan Frekuensi Pemberian Pupuk Organik Cair Hasil Perombakan Anaerob Limbah Makanan Terhadap Pertumbuhan Tanaman Sawi (Brassica juncea l.). Skripsi: Jurusan Biologi Fakultas MIPA Universitas Negeri Sebelas Maret.

Zulfitri. 2005. Analisis Jenis Dan Polybag Terhadap Pertumbuhan Serta Hasil Cabai (Capsicum Annum L.) Sistem Hidroponik. Bulletin Penelitian (8):1-10. 